Note

\title{
First record and new host record of the obligate dulotic ant, Polyergus bicolor (Hymenoptera: Formicidae), in Alberta, Canada
}

\author{
Christine E. Sosiak ${ }^{1, *}$, Mari West ${ }^{2}$, and JAmes R.N. Glasier ${ }^{3}$ \\ ${ }^{1}$ Federated Department of Biology, New Jersey Institute of Technology/Rutgers-Newark, Newark, New Jersey 07102 USA \\ ${ }^{2}$ Department of Entomology, University of California Riverside, Riverside, California 92521 USA \\ ${ }^{3}$ Métis Nation of Alberta, Environment Division, Edmonton, Alberta T5G X05 Canada \\ *Corresponding author: ces43@njit.edu
}

Sosiak, C.E., M. West, and J.R.N. Glasier. 2019. First record and new host record of the obligate dulotic ant, Polyergus bicolor (Hymenoptera: Formicidae), in Alberta, Canada. Canadian Field-Naturalist 133(4): 309-312. https://doi. org/10.22621/cfn.v133i4.2381

\begin{abstract}
We describe the discovery of Polyergus bicolor, an obligate slave-making ant species, as a new provincial record in Alberta. This species was previously known mostly from eastern Canada and the northeastern United States and has been sparsely collected: only once in the past 50 years. Polyergus bicolor was discovered parasitizing Formica podzolica, which is also a new host for the species. This discovery marks a significant expansion of both range and host for $P$. bicolor.
\end{abstract}

Key words: Polyergus bicolor; dulotic parasitism; range expansion; host expansion; Alberta; Formica podzolica

Polyergus (Latreille 1804) is a predominantly holarctic genus of ants that contains 14 species, 11 of which are present in North America (Trager 2013). All Polyergus display obligate dulotic behaviour (slave-making), making them a remarkable genus that has received a good deal of research interest.

Colony foundation occurs when a mated Polyergus queen enters a Formica nest, kills the queen, and usurps her role, with Formica workers taking care of her and her brood (Hölldobler and Wilson 1990). To maintain Formica worker populations in the colony, Polyergus workers locate a host nest, and then raid it for pupae, prepupae, and occasionally last-instar larvae. When the Formica pupae mature to adults in the Polyergus nest, they accept that nest as their own, and perform the majority of tasks within the colony (Trager 2013). Host Formica species vary, depending on the Polyergus species: some Polyergus will parasitize only one Formica species, while others are capable of parasitizing multiple species. Generally, the host species is from the Formica fusca group or the Formica pallidefulva group (Trager 2013).

In western North America, Polyergus is overwhelmingly represented by Polyergus mexicanus (Trager 2013; Glasier et al. 2016); in Idaho, P. breviceps is also present (Wheeler 1917; Smith 1947;
Trager 2013). (Note: there are generally no accepted common names for ants.) Polyergus bicolor was previously reported as restricted to eastern North America: Ontario to Illinois (Smith 1947; Wheeler 1968; Trager 2013). It was reported as far west as Saskatchewan and Montana by Wheeler (1917) as Polyergus rufescens bicolor. It was only confirmed as far west as the Dakotas by Trager (2013), who raised it to the status of species. Trager noted that he was unable to collect any P. bicolor during the course of his study within its historical range, save for one collection made in Wisconsin. In the last 50 years, he had found no $P$. bicolor collection records from its historical range (Trager 2013).

We first found P. bicolor in Alberta in summer 2017. We collected two colonies in Jarvis Bay Provincial Park, on Sylvan Lake, while collecting and observing Formica colony behaviour. Jarvis Bay Provincial Park is a drywood boreal forest characterized by mostly deciduous stands dominated by Trembling Aspen (Populus tremuloides Michaux), Balsam Poplar (Populus balsamifera L.), Black Spruce (Picea mariana (Miller) Britton, Sterns and Poggenburgh), and White Spruce (Picea glauca (Moench) Voss); prior records of $P$. bicolor note that it nests mostly in mesic forest, generally in rotten

$\overline{\text { A contribution }}$ towards the cost of this publication has been provided by the Thomas Manning Memorial Fund of the Ottawa Field-Naturalists' Club. 
stumps or fallen $\log$, thus habitat similar to Jarvis Bay (Trager 2013).

The specimens were collected by hand around the provincial park campsite after mistaking them for a species of the Formica rufa or Formica sanguinea species groups. They were found in domed dirt and debris mounds with the host species Formica podzolica, identified using published keys (Francoeur 1973; Glasier et al. 2013). Our Polyergus specimens were identified using Trager's revised key to global Polyergus species (Trager 2013). They differ from $P$. mexicanus, the other known Polyergus species in the area, by the degree of dark colouration on the abdomen and a complete lack of pilosity on both the vertex of the petiole and the pronotum (Glasier et al. 2013; Trager 2013).

A second collection occurred in July 2018 near Hay Lakes, Alberta, an area dominated by mixed deciduous woodlands (Trembling Aspen and Balsam Poplar) similar to Sylvan Lake. They were collected from a rounded mound within a grass meadow and were also using F. podzolica as a host. Polyergus bicolor has been formally recorded parasitizing both Formica neorufibarbis and Formica subaenescens, but not $F$. podzolica. The mounds in which we found $P$. bicolor were unlike their normal reported nesting sites, but this could be the result of their using a different host species.

This discovery represents a significant expansion of $P$. bicolor's previously known range, although it supports Wheeler's (1917) reports of P. bicolor in Saskatchewan as $P$. $r$. bicolor. Although the habitat where we found $P$. bicolor in Alberta is similar to the type of habitat from which it was previously known, the climate of Alberta is distinct from that of southern Ontario and the northeastern United States. The expansion of host species to include F. podzolica is also notable; Polyergus may use one or several hosts species but tends to show high fidelity to one host for a given population. Within a Polyergus species, if different populations are using different hosts, they are often highly specialized to their own host species. Populations show distinct chemical and genetic divergence from one another, perhaps reflecting incipient speciation (Torres et al. 2018). Because newly mated Polyergus queens typically stay with the host species of their parent colony, this fidelity is passed down from generation to generation (Hölldobler and Wilson 1990). Formica podzolica is widespread throughout North America and its range overlaps with that of $P$. bicolor in the northeastern United States (Wheeler and Kannowski 1994; Ellison et al. 2007); thus, it is difficult to say where host expansion took place. Further genetic work would shed light on potential divergence between $P$. bicolor pop- ulations in western and eastern North America, contingent on their host species.

\section{Voucher specimens}

Canada, Alberta: Sylvan Lake Jarvis Bay, $52.347^{\circ} \mathrm{N}, 114.091^{\circ} \mathrm{W}$ and $52.345^{\circ} \mathrm{N}, 114.089^{\circ} \mathrm{W}$, hand collected, 21 July 2017, C. Sosiak (Figure 1, personal collections of Christine Sosiak and Mari West).

Canada, Alberta: $4 \mathrm{~km}$ SE of Hay Lakes, Aspen Parkland, $53.165^{\circ} \mathrm{N}, 113.014^{\circ} \mathrm{W}$, hand collected, with F. podzolica, 27 July 2018, J.R.N. Glasier (Strickland Museum and personal collection of J.R.N. Glasier). Strickland Museum accession numbers: $P$. bicolor specimens UASM396245, UASM396246; F. podzolica specimens UASM396247, UASM396248.

\section{Author Contributions}

Writing - Original Draft: C.E.S.; Writing - Review \& Editing: C.E.S., M.W., and J.R.N.G.; Species Collection: C.E.S., M.W., and J.R.N.G.; Species Identification: C.E.S. and J.R.N.G.; Funding Acquisition: M.W.

\section{Acknowledgements}

We collected Polyergus specimens while conducting research funded by Alberta Conservation Association Grants in Biodiversity. Additional support for this work was provided in part by University of California Riverside, National Science Foundation Research Traineeship for Integrated Computational Entomology, award 1631776. We thank John Acorn, James Trager, Jessica Purcell, and Phillip Barden, as well as an anonymous reviewer, for their helpful comments on a draft of this manuscript.

\section{Literature Cited}

Ellison, A.M., S. Record, A. Arguello, and N.J. Gotelli. 2007. Rapid inventory of the ant assemblage in a temperate hardwood forest: species composition and assessment of sampling methods. Environmental Entomology 36: 766-775. https://doi.org/10.1093/ee/36.4.766

Francoeur, A. 1973. Révision taxonomique des espèces néarctiques du groupe Fusca, genre Formica (Formicidae, Hymenoptera). Mémoires de la Société Entomologique du Québec 3. Entomological Society of Quebec, Quebec, Canada.

Glasier, J.R.N., J.H. Acorn, S.E. Nielsen, and H. Proctor. 2013. Ants (Hymenoptera: Formicidae) of Alberta: a key to species based primarily on the worker caste. Canadian Journal of Arthropod Identification 22: 1104. https://doi.org/10.3752/cjai.2013.22

Glasier, J.R.N., S. Nielsen, J.H. Acorn, L.H. Borysenko, and T. Radtke. 2016. A checklist of ants (Hymenoptera: Formicidae) of Saskatchewan. Canadian Field-Naturalist 130: 40-48. https://doi.org/10.22621/cfn.v130i1.1791

Hölldobler, B., and E.O. Wilson. 1990. The Ants. Belknap (Harvard University Press), Cambridge, Massachusetts, USA. 

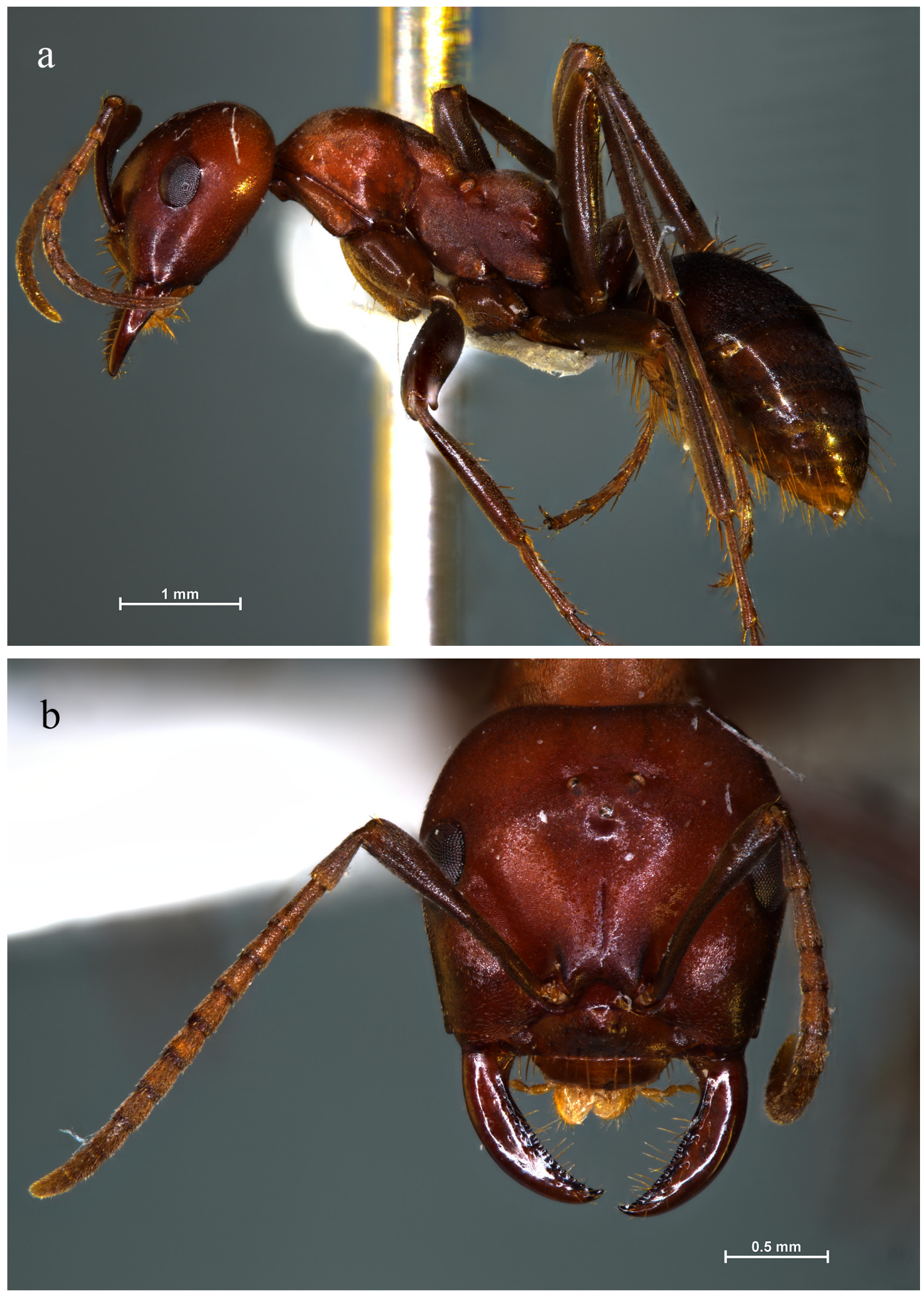

Figure 1. Lateral a. and frontal b. views of a Polyergus bicolor specimen collected in Jarvis Bay Provincial Park, Sylvan Lake. Photos: Christine Sosiak. 
Latreille, P.A. 1804. Tableau méthodique des insectes. Page 179 in Nouveau dictionnaire d'histoire naturelle. Edited by Société de Naturalistes et d'Agriculteurs. Déterville, Paris, France.

Smith, M.R. 1947. A study of Polyergus in the United States, based on the workers (Hymenoptera: Formicidae). American Midland Naturalist 38: 150-161.

Torres, C.W., M.A. Tonione, S.R. Ramirez, J.R. Sapp, and N.D. Tsutsui. 2018. Genetic and chemical divergence among host races of a socially parasitic ant. Ecology and Evolution 8: 11385-11398. https://doi.org/10.10 02/ece 3.4547

Trager, J.C. 2013. Global revision of the dulotic ant genus Polyergus (Hymenoptera: Formicidae, Formicinae, For- micini). Zootaxa 3722: 501-548. https://doi.org/10.11646/ zootaxa.3722.4.5

Wheeler, G.C., and P.B. Kannowski. 1994. Checklist of the ants of Michigan (Hymenoptera: Formicidae). Great Lakes Entomologist 26: 297-310.

Wheeler, J. 1968. Male genitalia and the taxonomy of Polyergus. Proceedings of the Entomological Society of Washington 70: 156-164.

Wheeler, W.M. 1917. The mountain ants of western North America. Proceedings of the American Academy of Arts and Science 52: 457-569.

Received 24 October 2019

Accepted 24 December 2019 